\title{
Hydrogen Internal Combustion Engine
}

\section{Ferenc Anisits ${ }^{*}$}

*Correspondence: Prof. Dr.-Ing Ferenc Anisits, anisits@aon.at, Address: A-4540 Bad Hall Eduardshöhe 36, Austria

\begin{abstract}
Hydrogen fuel constitutes an attainable alternative strategy, which can be implemented in the long term. This strategy can avoid the risk of commodity supply dependency (rare earths and copper) and can delay the still open decisions on emobility. Hydrogen internal combustion engines represent a doable and less expensive solution for using hydrogen than purchasing a new car equipped with a hydrogen fuel cell. Conventional piston engines can be switched to gas operation with relatively little change. This approach is environmentally more viable, as in a short time most vehicles can be switched to emission-free operation. Also, it can avoid the risk of commodity supply dependency (rare earths and copper) and can delay the still open decisions on e-mobility.
\end{abstract}

Keywords: Law (regularity) of evolution of technical systems, e-mobility, hydrogen mobility, hydrogen fuel, hydrogen internal combustion engines, bi-fuel motors, and BMW Hydrogen 7

\section{Introduction}

Based on my engineering experience acquired over a several decades long career, the development of all technical systems, their life period follows a slightly oblique S-shaped trajectory. Process development enables to determine the efficiency of profit/expense ratio over time. All technical advances and turnovers correspond to a multi-phase process. After a demanding launch (the invention itself), one starts a steep progressive development (growth through optimization and dynamization). Subsequently to reaching a certain point of development (maturity), a descending phase occurs (stagnation and exhaustion of the potential for further development). This technique is a common law of technology development, which applies to steam engines and internal combustion engines, as well. There is a continuous demand for technical shift to higher order systems, such as from sail plains to motorized aircrafts, jet planes, and rockets. Since all small-scale technical developments in fossil fuel-powered internal combustion engines are disproportionately expensive, any further progress becomes meaningless.

\section{Transition to higher level technologies}

In the future, advanced energy converters will be needed, which must meet multidimensional requirements. They must comply with climate and environmental protection constraints, and they should satisfy the need for renewable energy sources, raw materials supply, the necessary infrastructure, efficiency, costs, safety, and cross-sectoral applicability (universal usability). Unfortunately, all these criteria cannot be met 
simultaneously. As a rule, the leading parameter plays an essential role in technology shifts. Hence, velocity is the most important in aircrafts, the yield in energy conversion, and carbon dioxide emissions in the energy economy.

When solar and windmill parks are being installed to replace fossil fuels, renewable energy also leaves a significant ecological footprint. All space occupied from the surroundings and concrete-made platform installed are damaging nature. The lower the efficiency of solar panels, the greater the space for their placement and the greater the loss of natural land [1]. The specific land requirement relative to performance is the most favorable for nuclear energy plants.

There is a growing need for carbon neutrality [2], which implies to prioritize zero carbon dioxide emissions. In addition, a series of new questions must be addressed: (i) whether the unrestricted takeover of agricultural land for energy production can be justified? (ii) should one promote electricity produced by renewable energy sources or by nuclear plants?

Advances in technology are evolutionary, rather than leaping processes. As an appealing illustration of this statement, one should mention that airships did not serve directly for developing the jet engine.

\section{Energy carriers and converters}

Regularly, in technical science energy carriers and energy converters are defined below [3]:

(i) primary energy carriers are all energy containing materials found in nature, from which energy can be released via different conversions, such as mechanical work, chemical or physical procedures, or combustion. This category of energy carriers includes wood, oil, natural gas, coal, running water, wind, solar, and geothermal resources

(ii) renewable energy sources consist of a group of energy carriers, which exploit solar energy directly.

Energy converters or power converters perform the change of all types of energies into another form of energy (e.g., chemical to kinetic energy in an internal combustion engine). Windmills represent an early example of transforming the kinetic energy of wind into mechanical energy, the latter being used for pumping water and grinding grain [4]. Other energy-conversion systems are decidedly more complex, particularly those that use raw energy from fossil fuels and nuclear fuels to generate electrical power. Energy converters include steam machines, expansion machines, internal combustion engines, fuel cells, electric motors, generators, etc. Sustainable energy production is possible as water, solar, wind and nuclear power, and each of them impacts nature to different extents. Accidents of nuclear energy plants may be devasting.

\section{Electric cars without a battery}

Mechanical energy of the energy converter (propulsion engine) is transformed into work in transportation devices (on public roads, on railway, in air, on water, or by cableways) and in machinery (construction industry, agriculture, earthwork, transport machines, and industrial robots). Various devices and machines, which operate with fossil-free energy converters include electric motors, air-driven expansion machines, and hydrogen-fueled internal combustion engines. Electric motors can be operated with galvanic cells or energy converters, which use hydrogen fuel cells.

All technologies are evaluated based on their global ecological balance, which covers all phases of the technology's life cycle from raw material extraction and processing to transport, installation, operation, waste disposal, and waste management (disposal, recycling, and disposal). E-mobility is the primary objective of the climate protection strategy via introduction of carbonfree technology in transportation. Nonetheless, emobility accomplished with batteries does not alleviate the climate globally. Extraction of raw materials, their transport between continents [5], battery manufacturing, and battery charging with "dirty electricity," which implies environmental exposure to high-frequency voltage transients (HFVT) [6], and the battery end-oflife treatment of waste, all harm the environment and increase the global carbon footprint of the atmosphere. Because of the low specific energy of batteries, the use of this form of energy storage is restrained to urban operation of small vehicles. Even so, electric cars pose the risk of bursting in fire [7] during charging or testing. The conceptual KO criteria cannot be ignored or compensated either by state subsidies or by arbitrary zero-emission classification. There are two basics for electricity generation by renewable energy: storage and digital electricity grids [8]. The storage capacity of batteries is far behind hydrogen. Further advantages of hydrogen are (i) it can be distributed via pipelines (modified natural gas pipelines) and (ii) it enables the implementation of decentralized electrical service.

At the current state of the technology, electric cars without a battery represent the future of e-mobility. Hydrogen fuel cells can be used in all transport vehicles and machineries. From the technical standpoint, it is a justified question whether it makes sense to build two parallel infrastructures for the refueling of batteries (emobile subsets) and fuel cell cars?

Building a hydrogen economy is a primary objective. The second challenge is the universal application of the fuel cell concept. To avoid overload, it would be rational 
to pursue an easier, more cost effective, and more efficient avenue; prior to introducing e-mobility, one can convert the internal combustion engines to hydrogen fuel operation.

\section{Switching internal combustion engines to hydrogen operation}

Conventional piston engines can be switched to gas operation with relatively little change. The fuel used can be natural gas, biogas, wood gas, or hydrogen. In practice, gasoline-fueled cars are refitted to bi-fuel motors (natural gas and gasoline). This is a doable and less expensive solution for hydrogen than purchasing a new car equipped with a hydrogen fuel cell. This approach is environmentally more viable, as in a short time most vehicles can be switched to emission-free operation. Today, the average age of domestic passenger cars and buses is of 14 years. Should government financing support the conversion of most vehicles to hydrogen fuel operation, pollutant emissions would be reduced in the foreseeable future. By contrast, mass replacement of conventional cars with costly fuel cell cars is unlikely to succeed in the short term.

\section{Concept of BMW Hydrogen 7}

Built from 2005 to 2007 by German automobile manufacturer BMW, Hydrogen 7 embodied the world's first hydrogen internal combustion engine operated in a passenger car. One should emphasize that this vehicle was using an internal combustion engine, which burned hydrogen instead of getting energy from hydrogen via fuel cells.

Peculiarity of the vehicle was that hydrogen fuel could be switched to gasoline (it possessed two tanks, one for gasoline and one for hydrogen). This rendered the vehicle suitable for everyday use, as the number of hydrogen-refueling stations available to the public has been limited (as few as 14 in year 2012). BMW produced more than 100 replicas of this vehicle. These cars have not been sold, but instead the manufacturer offered them for use to known personalities. The 7-series limousine has a power of $192 \mathrm{~kW}$, an acceleration of $0-100 \mathrm{~km} / \mathrm{h}$ in $9.5 \mathrm{~s}$, its maximum speed being $219 \mathrm{~km} / \mathrm{h}$ [9].

Conversion of the conventional series gasoline motors to hydrogen operation requires relatively little change. The most important change concerns the inlet system and the installation of a new hydrogen dispensing valve. In addition to the gasoline pipeline, a second line was integrated, which was parallel to the hydrogen tank. The spark of the spark plugs in the hydrogen-air mixture triggered the combustion. For a more efficient seal, new piston rings have been used. To store hydrogen the vehicle was equipped with a second tank (Kryrotank). Hydrogen was introduced directly into the combustion chamber, under high pressure. Combustion product were water vapors and nitrogen oxide, the latter being reduced to quasi-zero by catalytical after-treatment. Emissions from the lubricating oil were also less than $1 \mathrm{~g} \mathrm{CO}_{2} / \mathrm{km}$. These novel hydrogen internal combustion engines can be designed according to diesel combustion or the gasoline spark ignition principle. The concept of a hydrogen tank can be implemented on the model of fuel cell cars produced in the Japanese and Southern Korea series. Hydrogen propulsion, unlike electric operation, does not require either the use of rare metals, or of heavy electric motors (about $80 \mathrm{~kg}$ ).

The concept of hydrogen mobility is shaping up in Europe. The Federal States of Rheinland-Pfalz and Bayern in Germany are building their energy strategy on hydrogen economy. Daimler Benz and MAN trucks are tested with hydrogen internal combustion engines. Particularly long-distance buses are suitable for hydrogen operation, because refuellers and storage facilities at terminals can be built in a centralized manner.

\section{Perspectives}

Producing hydrogen by night using electricity from nuclear plants and H2-mobility are tasks that can be achieved in the short term. Therefore, hydrogen fuel represents a doable alternative strategy that can be implemented in the long term. This strategy can avoid the risk of commodity supply dependency (rare earths and copper) and can delay the still open decisions on emobility.

\section{References}

[1] Anisits, F. "Backside of the energy revolution and emobility" (in Hungarian). Mérnök Újság (Engineer's newspaper), March 2021.

[2] "What is carbon neutrality and how can it be achieved by 2050?" In: News European Parliament (Created: March 10, 2019, Updated June 24, 2021) $<$ https://www.europarl.europa.eu/news/en/headlines/ society/20190926STO62270/what-is-carbon-neutralityand-how-can-it-be-achieved-by-2050> (Accessed: August 10, 2021.)

[3] Rosenqvist, J., Thollander, P., Wollin, J., Karlsson, M., Rohdin, P. Introduction to Industrial Energy Efficiency. Energy Auditing, Energy Management, and Policy Issues. Academic Press, 2020.

[4] Lee, K.-B., Lee, J.-S. Reliability Improvement Technology for Power Converters. Springer, 2017. 
[5] Anisits, F. "Sustainable electricity based on hydrogen technology," (in Hungarian). Service Engineer Newspaper, April 2021.

[6] de Vocht, F. "Dirty electricity": what, where, and should we care? Journal of Exposure Science \& Environmental Epidemiology 20, 399-405.

[7] Tesla Megapack Battery, the world's utmost battery caught fire during testing in Australia. See: Kolodny, L. (2021). "Tesla Megapack caught fire at Victorian Big Battery site in Australia", CNBC, July 30, 2021. https:// www.cnbc.com/2021/07/30/tesla-megapack-caught-fireat-victorian-big-battery-site-in-australia.html (Accessed: August 13, 2021.)

[8] Anisits, F. Ecological balance of car battery life cycle. University of Debrecen, Hungary, 2019.

[9] BMW HYDROGEN ENGINE REACHES TOP LEVEL EFFICIENCY. Press Club USA, Press Release, Dec. 3, 2009.

$<$ https://www.press.bmwgroup.com/usa/article/detail/ T0020216EN_US> (Accessed: August 11, 2021) 